\title{
EFEKTIVITAS PEMBERIAN TERAPI JUS PEPAYA DALAM MENURUNKAN TEKANAN DARAH PASIEN HIPERTENSI DI WILAYAH KERJA PUSKESMAS SUNGAI PIRING KABUPATEN INDRAGIRI HILIR TAHUN 2016
}

\author{
Erma Kasumayanti \\ Dosen FIK Universitas Pahlawan Tuanku Tambusai, Riau, Indonesia
}

\begin{abstract}
Abstrak
Penyakit darah tinggi atau hipertensi telah menjadi penyakit yang umum diderita oleh banyak masyarakat Indonesia. Jika hipertensi terjadi secara berkepanjangan, maka akan meningkatkan resiko terkena sroke, serangan jantung dan gagal ginjal kronis. Adapun cara untuk menurunkan tekanan darah penderita hipertensi salah satunya dengan pengobatan herbal menggunakan jus pepaya mengkal karena kandungan kalium didalam buah pepaya dapat meningkatkan kerja jantung. Tujuan penelitian ini adalah untuk mengetahui efektifitas pemberian jus pepaya dalam menurunkan tekanan darah pasien hipertensi. Metode penelitian ini adalah quasi experiment, dengan menggunakan rancanagan one group pre-test-posttest. Metode pengambilan sampel adalah purposive sampling. Populasi dalam penelitian ini adalah seluruh pasien hipertensi yang berkunjung ke Puskesmas yaitu sebanyak 460 orang. Jumlah sampel pada penelitian ini yaitu sebanyak 30 orang. Alat ukur yang digunakan adalah alat pengukur tekanan darah (sphygmanometer air raksa) dan lembar observasi. Analisa yang digunakan adalah analisa univariat dan bivariat dengan menggunakan uji $t$-dependent. Hasil penelitian menunjukkan adanya perbedaan secara bermakna terhadap penurunan tekanan darah pasien hipertensi setelah diberikan jus pepaya dengan nilai $p$-value $(0,000)<\alpha(0,05)$, dengan rata-rata penurunan tekanan darah $10 \mathrm{mmHg}$ sampai 30 mmHg. Hasil penelitian ini diharapkan kepada pasien hipertensi untuk dapat menggunakan terapi non farmakalogi dengan mengkonsumsi jus pepaya sebagai salah satu alternatif yang aman untuk menurunkan tekanan darah.
\end{abstract}

Keywords : Hipertensi, jus pepaya

Bibliography : $24(2005-2016)$

\section{PENDAHULUAN}

Penyakit darah tinggi atau hipertensi telah menjadi penyakit yang umum diderita oleh banyak masyarakat Indonesia.

Hipertensi adalah suatu keadaan dimana seseorang mengalami peningkatan tekanan darah di atas normal yang mengakibatkan peningkatan angka kesakitan (morbiditas) dan angka kematian (mortalitas) (Triyanto, 2014).

Salah satu penyebab yang sering kali menjadi penyebab hipertensi adalah arterosklerosis atau penebalan dinding arteri yang menyebabkan hilangnya elastisitas pembuluh darah (Kholish, 2011).

World Health Organization (WHO) mencatat pada tahun 2012 sedikitnya sejumlah 839 juta kasus 
hipertensi, diperkirakan menjadi 1,15 milyar pada tahun 2025 atau sekitar $29 \%$ dari total penduduk dunia, dimana penderitanya lebih banyak pada wanita (30\%) dibanding pria (29\%). Berdasarkan hasil Riset Kesehatan Dasar (Riskesdas) 2007 menunjukkan, sebagian besar kasus hipertensi di masyarakat belum terdiagnosis, hal ini terlihat dari hasil pengukuran tekanan darah pada usia 18 tahun ke atas ditemukan prevalensi hipertensi di Indonesia sebesar $31,7 \%$, dimana hanya $7,2 \%$ penduduk yang sudah mengetahui memiliki hipertensi dan hanya $0,4 \%$ kasus yang minum obat hipertensi.(Kemenkes RI, 2012).

Hasil Riset Kesehatan Dasar (Riskesdas) tahun 2013 menunjukkan prevalensi hipertensi berdasarkan pengukuran tekanan darah di Propinsi Riau sebesar 20,9\%. Jika saat ini penduduk Propinsi Riau sebesar 6.358.636 jiwa maka terdapat 1.328.954 jiwa yang menderita hipertensi (Pusat Data dan Informasi Kementerian Kesehatan RI, 2014).

Hipertensi yang tidak segera diatasi bisa menimbulkan gejala seperti sakit kepala, kelelahan, mual, muntah, sasak napas, terengahengah, gelisah, pandangan mata kabur dan berkunang kunang, emosional, telinga berdengung, sulit tidur, tengkuk terasa berat, nyeri kepala bagain belakang,dan didada, otot lemah, terjadi pembekakan pada kaki dan pergelanagn kaki, keringat berlebihan, kulit tampak pucat dan kemerahan, denyut jantung yang kuat, cepat, dan tidak teratur, impotensi, pendarahan diurine, bahkan mimisan. Jika hipertensi ini terjadi secara perkepanjangan, maka akan meningkatkan resiko terkena stroke, serangan jantung dan gagal ginjal kronis bahkan pada hipertensi berat dapat menyebabkan ensepalopati hipertensif, yaitu penurunan kesadaran bahkan koma (Noviyanti, 2015).

Hipertensi jika tidak dilakukan penanganan, sekitar $70 \%$ pasien hipertensi kronis akan meninggal karena jantung koroner atau gagal jantung, $15 \%$ terkena kerusakan jaringan otak, dan $10 \%$ mengalami gagal ginjal. Sejalan dengan bertambahnya usia hampir setiap orang mengalami kenaikan tekanan darah dan akan terus meningkat sampai usia 80 tahun (Noviyanti, 2015).

Dari pengalaman klinis diketahui penggunaan obat-obat sintesis dapat mengendalikan tekanan darah. Sayangnya pengobatan secara farmakologi bila digunakan dalam jangka waktu lama biasanya mahal dan berefek samping. Hal ini menimbulkan masalah baik dari segi kesehatan maupun biaya. Sehingga masalah tersebut dijadikan alasan bagi masyarakat untuk menggunakan pengobatan alternatif atau pengobatan non farmakologi (Jain, 2011).

Beberapa jenis pengobatan alternatif yang dapat digunakan untuk menurunkan tekanan darah adalah akupresur (akupuntur tanpa jarum), pengobatan herbal dari Cina, terapi jus, pijat, yoga, aromaterapi, pernafasan dan relaksasi, biofeedback, meditasi dan hipnosis (Jain, 2011).

Beragam terapi alternatif yang telah terbukti secara ilmiah yang dapat menurunkan tekanan darah salah satunya jus papaya mengkal. Tanaman pepaya termasuk jenis tanaman tropis yang mudah tumbuh dimana saja diwilayah Indonesia, Selain itu buah pepaya mengkal 
mengandung antioksidan, tinggi serat dan telah terbukti khasiatnya untuk menormalkan tekanan darah (Jain, 2011). Buah pepaya mengkal banyak mengandung zat-zat yang bermanfaat bagi tubuh, terutama untuk pembuluh darah. Buah pepaya mengkal kaya akan vitamin A $(\beta$ Karotena), vitamin $\mathrm{C}$, enzim papapin serta kalium (Kholish, 2011).

Menurut penelitian yang dilakukan oleh Mariani (2007), tentang "pengaruh pemberian jus pepaya, jus semangka dan jus melon terhadap penurunan tekanan darah sistolik dan diastolic" mengatakan bahwa ada pengaruh pemberian jus pepaya terhadap penurunan tekanan darah sistolik dan diastolik dengan penurunan tekanan darah $20 \mathrm{mmHg}$ - $30 \mathrm{mmHg}$. Penelitian lain dilakukan oleh Yuliza (2014), tentang "efektivitas sari buah pepaya mengkal (carica papaya) terhadap tekanan darah pada pasien hipertensi" mengatakan bahwa pemberian jus pepaya dalam waktu tertentu dapat menurunkan tekanan darah pada pasien hipertensi secara signifikan dengan penurunan tekanan darah sistol sebesar 24,29 $\mathrm{mmHg}$ dan penurunan tekanan darah diastole sebesar 18,39 $\mathrm{mmHg}$.

Berdasarkan data dari Dinas Kesehatan Indragiri Hilir Tahun 2015, hipertensi masuk kedalam sepuluh besar kasus penyakit terbanyak di Indragiri Hilir yaitu menempati urutan kedua dengan jumlah 29274 kasus. Kasus terbanyak terjadi di puskesmas Sungai Piring dengan jumlah pasien 460 orang. Berdasarkan survei pendahuluan yang dilakukan di Puskesmas Sungai Piring pada tanggal 25 Februari 2016, dari 20 orang yang berobat sebanyak 13 orang $(65 \%)$ mengalami hipertensi, dengan kategori hipertensi yang ringan dan sedang. Dari 13 orang $(65 \%)$ pasien yang mengalami hipertensi mengatakan kepalanya merasa sakit, tengkuk terasa berat, dan mata berkunang-kunang. Sebanyak 8 orang $(61,53 \%)$ pasien mengatakan hanya meminum obatobatan dari puskesmas, dan sebanyak 5 orang $(38,46 \%)$ mengatakan hanya istirahat saja dan diberi minyak angin atau balsem. Sedangkan untuk penggunaan jus papaya untuk menurunkan hipertensi belum pernah dilakukan.

Pada kondisi hipertensi ringan dan sedang terapi jus pepaya dapat menurunkan tekanan darah sekitar $20-30 \mathrm{mmHg}$ tanpa menimbulkan efek samping. Sedangkan pada penderita hipertensi berat dapat mengurangi jumlah obat dengan dosis yang rendah jika menggunakan terapi jus pepaya. (Jain. 2011). Namun manfaat buah pepaya terhadap penurunan tekanan darah belum banyak diketahui oleh masyarakat luas sehingga pohon pepaya yang tumbuh dipekarangan rumah pun sering tidak dimanfaatkan, padahal buah pepaya merupakan salah satu bahan baku untuk pengobatan alternatif yang dapat menurunkan tekanan darah pada penderita hipertensi dengan tingkat keamanan relatif lebih tinggi dari pada obat sintesis atau kimia.

Berdasarkan fenomena di atas, maka peneliti tertarik untuk melakukan penelitian dengan judul penelitian "Efektivitas Pemberian Terapi Jus Pepaya dalam Menurunkan Tekanan Darah Pasien Hipertensi Di Wilayah Kerja Puskesmas Sungai Piring Kabupaten Indragiri Hilir".

\section{METODE}


Pada penelitian ini menggunakan jenis penelitian kuantitatif. Desain penelitian yang digunakan yaitu quasi experiment, dan rancangan yang digunakan one group pre-test-posttest yaitu dengan mengobservasi sebanyak 2 kali sebelum dan sesudah diberikan perlakuan. Kelompok diobservasi sebelum dilakukan intervensi, kemudian diobservasi kembali setelah intervensi di lain waktu yang telah ditentukan (setiadi, 2007). Penelitian ini dilakukan pada tanggal 25 April s/d 29 April 2016 di Wilayah Kerja Puskesmas Sungai Piring Kabupaten Indragiri Hilir. Metode pengambilan sampel adalah purposive sampling. Populasi dalam penelitian ini adalah seluruh pasien hipertensi yang berkunjung ke Puskesmas yaitu sebanyak 460 orang. Adapun jumlah sampel sebanyak 30 orang. Alat ukur yang digunakan adalah alat pengukur tekanan darah (sphygmanometer air raksa) dan lembar observasi. Analisa yang digunakan adalah analisa univariat dan bivariat dengan menggunakan uji t-dependent.

\section{HASIL PENELITIAN}

\section{Analisa Univariat}

Hasil analisa univariat berdasarkan hasil penelitian menunjukkan bahwa rerata usia sebagian responden berada pada kategori lansia akhir 56-65 tahun sebanyak 16 orang $(53,3 \%)$, sebagian besar responden berjenis kelamin perempuan sebanyak 23 orang $(76,7 \%)$ dan sebagaian besar responden bekerja sebagai IRT sebanyak 22 orang (73.3\%). Sedangkan rerata tekanan darah sistolik sebelum pemberian jus pepaya mengkal dari 30 responden sebagian besar responden dengan tekanan darah sistoliknya 140
mmHg sebanyak 18 orang $(60.0 \%)$ dan rerata tekanan darah diastolik sebelum pemberian jus pepaya mengkal sebagian besar responden tekanan darah diastoliknya 90 mmHg sebanyak 18 orang $(60.0 \%)$. Dan berdasarkan rerata tekanan darah sistolik setelah pemberian jus pepaya mengkal dari 30 responden sebagian besar responden tekanan darah sistoliknya turun yaitu 130 mmHg sebanyak 18 orang $(60.0 \%)$ dan rerata tekanan darah diastolik setelah pemberian jus pepaya mengkal hampir seluruh responden tekanan darah diastoliknya turun yaitu $80 \mathrm{mmHg}$ sebanyak 25 orang $(83,3 \%)$.

\section{Analisa Bivariat}

Dari hasil penelitian yang telah dilakukan maka diperoleh hasil bahwa terdapat perbedaan rerata nilai mean sebelum diberikan jus pepaya mengkal (Pretest) sebesar 2,00 dan setelah diberikan jus pepaya mengkal (Posttest) sebesar 1.10 dan nilai $p$-value sebesar 0,000 ( $\mathrm{P}<0,05)$, dengan demikian dapat disimpulkan bahwa $\mathrm{Ha}$ diterima artinya jus pepaya mengkal efektif terhadap penurunan tekanan darah pada pasien hipertensi di wilayah kerja Puskesmas Sungai Piring kabupaten Indragiri Hilir Tahun 2016.

\section{PEMBAHASAN}

\section{Tekanan Darah Responden sebelum diberikan Terapi Jus Pepaya Mengkal pada Pasien Hipertensi}

Hasil analisis data tekanan darah sebelum diberikan terapi jus pepaya mengkal didapat bahwa seluruh responden menderita hipertensi yaitu sebanyak 30 orang 
(100\%) dengan sistolik 140-160 $\mathrm{mmHg}$ dan diastolic 90-100 mmHg. Rentang usia sebagian responden adalah masa lansia akhir 56-65 tahun sebanyak 16 orang $(53,3 \%)$. Hal ini didukung oleh Noviyanti (2015) yang mengatakan bahwa sejalan dengan bertambahnya usia, hampir setiap orang mengalami kenaikan tekanan darah dan akan terus meningkat sampai usia 80 tahun. Pertambahan usia juga akan menyebabkan perubahan pada jantung, pembuluh darah dan perubahan hormonal (Sutomo, 2009).

Dari 30 responden yang mengalami hipertensi berdasarkan jenis kelamin didapatkan bahwa sebagian besar responden berjenis kelamin perempuan sebanyak 23 orang $(76,7 \%)$. Hal ini bisa terjadi karena pada perempuan lebih beresiko terkena hipertensi setelah umur 55 tahun setelah menopause, kejadian hipertensi meningkat pada perempuan karena pada masa menopause penurunan hormon estrogen dapat meningkatkan tekanan darah (Triyanto, 2014).

Berdasarkan jenis pekerjaan didapatkan bahwa sebagaian besar responden bekerja sebagai IRT (Ibu Rumah Tangga) sebanyak 22 orang (73.3\%). Dengan pekerjaan tersebut para ibu ini banyak menghabiskan waktunya dengan rutinitas pekerjaan rumah sehingga mereka merasa enggan dan jarang untuk melakukan olahraga. Sementara Olahraga yang teratur cenderung akan membuat seseorang memiliki tekanan darah normal dan menjadi lebih sehat dibandingkan dengan mereka yang tidak berolahraga (Jain, 2011). Menurut asumsi peneliti, terjadinya peningkatan tekanan darah pada sering disebabkan oleh kebiasaan hidup penderita hipertensi seperti konsumsi makanan yang mengandung kadar garam yang tinggi lebih dari $1.500 \mathrm{mg}$ atau satu sendok teh perhari serta didukung oleh letak wilayah yang dikelilingi oleh laut sehingga masyarakat lebih sering mengkonsumsi makanan laut seperti kepiting, udang galah dan kerang. Selain itu faktor lainnya adalah responden yang sering mengalami stress, seperti ibu rumah tangga yang harus terus menerus dalam melakukan pekerjaan rumah, dan kurang melakukan olahraga yang teratur sehingga terjadi penurunan dalam relaksasi otot polos pembuluh darah dan menurunkan kemampuan distensi daya renggang pembuluh darah dalam mengakomodasi volume darah yang dipompa kejantung

2. Efektivitas Pemberian Terapi Jus Pepaya Mengkal pada Pasien Hipertensi

Hasil penelitian menunjukkan tekanan darah sesudah diberikan terapi jus pepaya mengkal, seluruh responden yang sebelumnya menderita hipertensi sebanyak 30 orang (100\%) dengan sebagian besar sistoliknya $140 \mathrm{mmHg}$ sebanyak 18 orang $(60.0 \%)$ dan sebagian besar diastoliknya 90 mmHg sebanyak 18 orang $(60.0 \%)$ terjadi penurunan tekanan darah yaitu sebagian besar responden tekanan darah sistoliknya turun yaitu $130 \mathrm{mmHg}$ sebanyak 18 orang $(60.0$ $\%$ ) dan hampir seluruh responden diastoliknya turun yaitu $80 \mathrm{mmHg}$ sebanyak 25 orang $(83,3 \%)$ dengan rerata penurunan tekanan darah 10 $\mathrm{mmHg}$ sampai $30 \mathrm{mmHg}$. Ini membuktikan bahwa jus pepaya dapat menetralisir tekanan darah. Hal ini karena pepaya mengandung kalium. Kalium (potassium) yang merupakan ion utama didalam cairan intraseluler. Cara kerja 
kalium adalah kebalikan dari natrium. Konsumsi kalium yang banyak dan rutin terus menerus akan meningkatkan konsentrasinya didalam cairan intraseluler, sehingga cenderung menarik cairan dari bagian ekstraseluler dan menurunkan tekanan darah (Jain, 2011). Hasil penelitian ini sejalan dengan penelitian yang dilakukan oleh Mariani (2007), tentang "pengaruh pemberian jus pepaya, jus semangka dan jus melon terhadap penurunan tekanan darah sistolik dan diastolic" mengatakan bahwa ada pengaruh pemberian jus pepaya terhadap penurunan tekanan darah sistolik dan diastolik dengan penurunan tekanan darah $20 \mathrm{mmHg}$ $-30 \mathrm{mmHg}$.

Hasil uji T-Dependent (Paired Samples Test) mean tekanan darah pretest dan postest menunjukkan ada perbedaan antara hasil pengukuran tekanan darah responden sebelum diberikan terapi jus pepaya (pretest) sebesar 2,00 dan setelah diberikan terapi jus pepaya (postest) sebesar 1,10 dengan nilai $p$-value sebesar 0,000 atau nilai $p$-value $<0,05$, artinya ada perbedaan yang signifikan mean tekanan darah sebelum dan setelah pemberian terapi jus pepaya mengkal dengan demikian dapat disimpulkan bahwa Ha diterima. Hal ini menunjukkan bahwa pemberian terapi jus pepaya efektif dalam menurunkan tekanan darah pasien hipertensi

Menurut Kholish, (2011)

Kandungan zat-zat kimia yang terdapat didalam buah pepaya sangat bermanfaat bagi tubuh, terutama pada pembuluh darah. Vitamin A ( $\beta$-Karotena $)$ dan vitamin $C$ memiliki kemampuan sebagai antioksi dan yang berperan penting dalam mencegah dan memperbaiki kerusakan pembuluh darah akibat aktifitas molekul radikal bebas. Sedangkan $\quad \beta$-Karotena merupakan suatu senyawa yang akan dikonversikan untuk menjadi vitamin A oleh tubuh. Vitamin A biasanya hanya dikenal sebagai zat gizi essensial untuk daya penglihatan, vitamin A juga memiliki peran yang sangat penting dalam menetralisir tekanan darah, vitamin A merupakan salah satu antioksidan alami yang dapat menghambat oksidasi lemak dan menghambat terjadinya kerusakan dinding pembuluh darah. Vitamin A yang dikonsumsi secara oral akan menimbulkan efek setelah $1-2$ jam dan mencapai puncaknya setelah $4-5$ jam (Kholish, 2011).

Dalam penelitian ini tekanan darah responden diukur minimal 1 jam setelah pemberian terapi jus pepaya sehingga didapatkan penurunan tekanan darah responden dan membuktikan bahwa telah terjadi pengaruh dari jus pepaya. Vitamin $\mathrm{C}$ juga merupakan antioksidan alami yang berfungsi mengikat oksigen sehingga tidak mendukung reaksi oksidasi, membantu menjaga kesehatan sel dan membangun sel-sel yang sudah rusak seperti kerusakan pada dinding pembuluh darah. Vitamin $\mathrm{C}$ berperan penting untuk menjaga dan memperbaiki sel-sel dinding pembuluh darah yang rusak akibat aktifitas molekul radikal bebas sehingga elastisitas pembuluh darah tetap terjaga, tekanan darah normal dapat dipertahankan. Vitamin $\mathrm{C}$ 
diserap secara cepat didalam usus (Ainul, 2010).

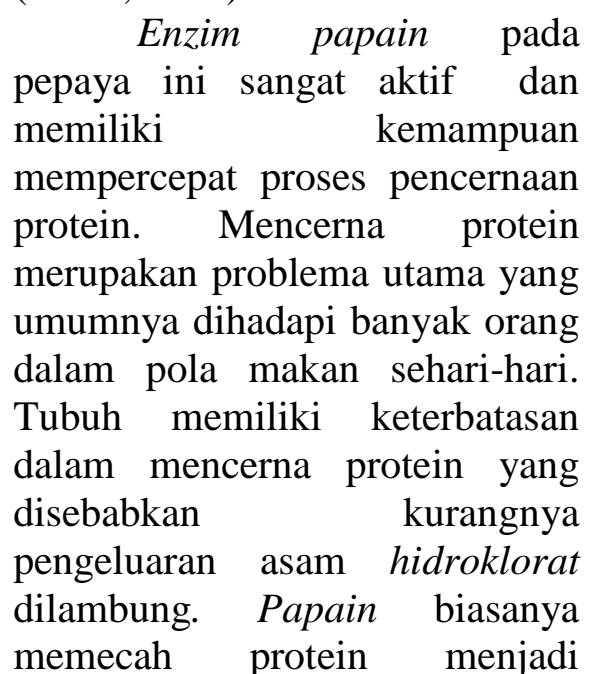
arginin. Proses pembentukan arginin mempengaruhi produksi hormon pertumbuhan manusia Human Growth Hormone (HGH). HGH ini membantu kesehatan otot dan mengurangi pertumbuhan lemak dalam tubuh. Papain juga dapat memecah makan yang mengandung protein hingga terbentuk berbagai senyawa asam amino yang bersifat autointoxicating atau otomatis menghilangkan terbentuknya subtansi yang tidak diinginkan akibat pencernaan yang tidak sempurna. Tekanan darah tinggi merupakan salah satu penyakit yang muncul karena proses pencernaan makanan yang tidak sempurna (Kholish, 2011).

Menurut penelitian lain yang dilakukan oleh Yuliza dalam sebuah jurnal yang berjudul "efektifitas sari buah pepaya mengkal (carica pepaya) terhadap tekanan darah pada pasien hipertensi", mengatakan bahwa penggunaan terapi jus pepaya dalam waktu tertentu dapat menurunkan tekanan darah pada pasien hipertensi secara signifikan dengan penurunan tekanan darah sistole sebesar 24,29 mmhg dan penurunan tekanan darah diastolic sebesar $18,39 \mathrm{mmHg}$.

Vitamin A, vitamin C, enzim papain dan kalium yang terkandung dalm buah pepaya berfungsi dalam memperbaiki organ-organ sirkulasi. Belum ada hasil penelitian atau sumber yang menyatakan bahwa zat-zat tersebut dapat menyebabkan hipotensi karena fungsinya adalah menetralisir tekanan darah, sehingga tekanan darah menjadi normal (Kholis, 2011).

Dengan demikian dengan pemberian jus pepaya secara terus menerus terbukti dapat menurunkan tekanan darah pasien hipertensi dengan ratarata penurunan tekanan darah 10 $\mathrm{mmHg}$ sampai $30 \mathrm{mmHg}$.

\section{KESIMPULAN DAN SARAN}

Dari hasil penelitian dapat disimpulkan bahwa :

1. Sebelum dilakukan pemberian terapi jus pepaya mengkal seluruh responden menderita hipertensi yaitu sebanyak 30 orang dengan sebagian besar responden tekanan darah sistoliknya $140 \mathrm{mmHg}$ sebanyak 18 orang dan sebagian besar responden tekanan darah diastoliknya $90 \mathrm{mmHg}$ sebanyak 18 orang.

2. Setelah dilakukan pemberian terapi jus pepaya mengkal sebagian besar responden tekanan darah sistoliknya turun yaitu 130 mmHg sebanyak 18 orang dan hampir seluruh responden tekanan darah diastoliknya turun yaitu $80 \mathrm{mmHg}$ sebanyak 25 orang. 
3. Pemberian terapi jus pepaya mengkal efektif dalam menurunkan tekanan darah pasien hipertensi di Wilayah Kerja Puskesmas Sungai Piring Kabupaten Indragiri Hilir tahun 2016

\section{Saran}

Adapun saran yang dapat diberikan berdasarkan hasil penelitian adalah sebagai berikut

a. Bagi pihak Puskesmas Sungai Piring Kabupaten Indragiri Hilir diharapkan dapat mensosialisasikan manfaat jus papaya mengkal sebagai alternatif terapi yang aman untuk menurunkan tekanan darah pada penderita hipertensi.

b. Bagi pasien yang menderita hipertensi diharapkan dapat mengkonsumsi jus papaya mengkal secara rutin bila terjadi peningkatan tekanan darah.

\section{DAFTAR PUSTAKA}

Anonim. (2013). About High Blood Pressure.

http://www.searo.who.int/entity/ world health day/HBP_WHD_2013/en. diperoleh tanggal 9 April 2016.

Anonim. (2012). Masalah Hipertensi Di Indonesia.

http://www.depkes.go.id/article /view/1909/masalah-hipertensidi-indonesia.html. diperoleh tanggal 9 April 2016.

Anonim, (2009). Kategori Umur. https://www.scribd.com/doc/162 685921/usia-menurut-depkes. diperoleh tanggal 25 mei 2016.
As-Sayyid Muhammad. (2013). Kitab Obat Hijau. Tinta Medina : PT Tiga Serangkai.

Burn, N., \& Grove, S. K. (2005). The pratice of nursing research: Conduct, critique, and utilization. $\left(5^{\text {th }}\right.$ ed). Missouri: Elsevier Saundersa.

Delp \& Manning. (2007). Major diagnosis fisik. Jakarta: buku kedokteran EGC

DepKes RI. (2014). Pharma Cheutical Care untuk Penyakit Hipertensi. http//www.4shared.com/get/1157 5a76/Hipertensi.Html.sessionid= 67c47f96c77ace...hipertensi www.Litbang. Depkeks.go.id/simnas4 day_2 Hipertensi.pdf. Diakses tanggal 10 April 2016.

Gunawan, L. (2007). Hipertensi tekanan darah tinggi. Yogyakarta: Penerbit kansius.

Hastono, S. P. (2007). Basic data analysis for health research training: Analisis data kesehatan. Jakarta: FKM UI.

Herbie, Tandi. (2015). Kitab tanaman berhasiat obat. Yogyakarta: Octopus Publishing House.

Hidayat, A. A. A. (2014). Riset keperawatan dan teknik penulisan ilmiah. Jakarta: Salemba Medika.

Jain, Ritu. (2011). Pengobatan alternatif untuk mengatasi tekanan darah. Jakarta: PT Gramedia Pustaka Utama.

Kholish, Nur. (2011). Bebas hipertensisSeumur hidup dengan herbal. Yogyakarta: Real Books. 
Mariani, E. (2007). Pengaruh Pemberian Jus Pepaya (Carica Papaya), Jus Semangka (Citrullus Vulgaris) Dan Jus Melon (Cucumis Melon) Terhadap Penurunan Tekanan Darah Sistolik Dan Diastolik. http:www. eprints.undip.ac.id. diperoleh tanggal 10 Maret 2016.

Mboi, $N$ (2013). Angka Kecukupan Gizi,

http://gizi.depkes.go.id/permenke s-tentang-angka-kecukupan-gizi. diperoleh tanggal 21 April 2016.

Notoadmodjo, S. (2010). Metodologi penelitian kesehatan. Jakarta : Rineka Cipta.

Nursalam. (2008). Konsep dan penerapan metodologi penelitian ilmu keperawatan. Jakarta: Salemba Medika.

Novianty. (2015). Hipertensi kenali, cegah, \& obati. Yogyakarta : Note book.

Setiadi. (2007). Konsep dan penulisan riset keperawatan. Yogyakarta: Graha Ilmu.

Shanty, Meita. (2011). Silent killer disease. Jogjakarta: PT Buku kita.

Sivakali, Narayan. (2011). Terapi jus buah-buahan dan sayursayuran. Jakarta : Prestasi Pustaka.

Sutomo, B (2009). Menu sehat penakluk hipertensi. Jakarta: Demedia Pustaka.

Triyanto, Endang. (2014). Pelayanan keperawatan bagi penderita hipertensi secara terpadu. Yogyakarta: Graha Ilmu.
Yuliza, E., Sabrian, F., \& Hasanah, O. (2014). Efektivitas Sari Buah Pepaya Mengkal (Carica Papaya) Terhadap Tekanan Darah Pada Pasien Hipertensi. http:www. jom.unri.ac.id. diperoleh tanggal 10 Maret 2016. 